\title{
Electrode Function (pH Response), Hygroscopicity, and Chemical Durability of Soda-Lead Oxide-Silica Glasses
}

\author{
By Donald Hubbard, Mason H. Black, and Gerald F. Rynders
}

\begin{abstract}
The $\mathrm{pH}$ response, hygroscopicity, and chemical durability of a series of $\mathrm{Na}_{2} \mathrm{O}-\mathrm{PbO}-\mathrm{SiO}_{2}$ (soda-lead oxide-silica) glasses have been investigated. The results obtained are in complete accord with the data previously published for a series of $\mathrm{Na}_{2} \mathrm{O}-\mathrm{CaO}-\mathrm{SiO}_{2}$ glasses and show that: 1. Glasses of very. low hygroscopicity yield electrodes whose $\mathrm{pH}$ responses fall appreciably below the theoretical 59 millivolts per $\mathrm{pH}$ at $25^{\circ} \mathrm{C} ; 2$. electrodes prepared from glasses of poor chemical durability also fail to develop the full theoretical voltage.

When the approximate compositions at which changes in the primary phase appear for the $\mathrm{Na}_{2} \mathrm{O}-\mathrm{PbO}-\mathrm{SiO}_{2}$ system are superimposed upon the $\mathrm{pH}$ response and chemical durability curves, the marked changes in these properties appear to reflect some of the critical compositions of the phase equilibrium diagram.

The chemical durability data obtained by the interferometer procedure indicate that the property of swelling in acid solutions is much more universal for silicate glasses than previously realized.
\end{abstract}

\section{Introduction}

All glasses, when immersed in aqueous solutions, develop an electromotive force [1 to 6$],{ }^{1}$ which in some cases serves as a reliable indicator of the hydrogen ion activity of the solution in quantitative accord with the prediction of the Nernst equation, $\Delta E=$ $0.000198 T \Delta \mathrm{pH}[7,8]$. Nevertheless, many glasses, show little or no $\mathrm{pH}$ response, whereas still others give the theoretical increment of voltage over only a limited $\mathrm{pH}$ range [1, 9 to 11]. From this apparent chaotic $\mathrm{pH}$ performance of glasses of different compositions have emerged certain definite characteristics of behavior, as follows:

1. Glasses of very low hygroscopicity or low water content produce electrodes that fail to develop the theoretical $59 \mathrm{mv}$ per $\mathrm{pH}$ at $25^{\circ} \mathrm{C}[1,6,12,13]$.

2 . Electrodes prepared from glasses of very poor chemical durability also fail to develop the full theoretical voltage $[13,14]$.

3 . Only those glasses having both adequate hygroscopicity and uniform chemical durability over an extended $\mathrm{pH}$ range produce electrodes that approximate the correct $\mathrm{pH}$ response $[7,12,13,15]$.

4. Voltage departures (errors) for electrodes prepared from $\mathrm{pH}$ responsive glasses occur in those solutions that cause an appreciable change in the attack on the glass, such as strong alkaline and hydrofluoric acid solutions [5, 13, 15, 17].

5. Voltage departures that appear in solutions of a dehydrating nature, such as strong $\mathrm{H}_{2} \mathrm{SO}_{4}$ and acetic acid [11], as well as in nonaqueous solutions such as ethanol, are accompanied by detectable changes in the surface of the glass, notably the repression of swelling [6 (p. 81), 16, 17].

In the present investigation, the hygroscopicity, chemical durability, and $\mathrm{pH}$ response of a series of $\mathrm{Na}_{2} \mathrm{O}-\mathrm{PbO}-\mathrm{SiO}_{2}$ glasses were studied for the purpose of determining if the above generalizations are valid for this series, and also to observe if the above properties reflect any of the critical compositions of the phase equilibrium diagram.

\footnotetext{
${ }^{1}$ Figures in brackets indicate the literature references at the end of this paper.
}

\section{Experimental Procedure}

The hygroscopicity data were obtained by weighing the water "sorbed" [18] by powdered samples of the glasses exposed for $1-$ and 2 -hr periods, to the high humidity maintained by a saturated solution of $\mathrm{CaSO}_{4} \cdot 2 \mathrm{H}_{2} \mathrm{O}$ at $25^{\circ} \mathrm{C}[12,13]$. The samples consisted of approximately $1.5 \mathrm{~g}$ of the powdered glass that passed through a Tyler standard 150 mesh sieve. $^{2}$ In order to make a legitimate comparison between glasses differing greatly in density, the hygroscopicity values are reported as milligrams of water sorbed per cubic centimeter, that is, water sorbed times the density of the glass divided by the weight of the sample.

The chemical durability determinations were made by the interferometer procedure $[15,19,20]$, which consists of determining the displacement of fringes by the alteration of the surface of the experimental glass after partial immersion in the test solution. Swelling is plotted in all figures as negative attack. To make the results comparable with previous publications $[13,14,15,17,21,22]$ the exposures were made at $80^{\circ} \pm 0.2^{\circ} \mathrm{C}$ to BrittonRobinson universal buffer solutions [23] ranging from $\mathrm{pH} 2$ to 11.8. All values are reported for a 6 -hr period, although the durabilities for many of the glasses were so poor that exposure times had to be reduced in order to keep the attack values within the limitations of the interferometer and preserve the optical quality of the surfaces. In one extreme case it was necessary to reduce the time of exposure to 5 secs.

The experimental electrodes were made by blowing a small thin-walled bulb on the end of tubing, which was drawn from the melts at the time of pouring. The inner electrical connection was established by filling the bulb and a portion of the stem with mercury $[2,24]$. The emf measurements were made at room temperature with a Beckman $\mathrm{pH}$ meter, model $\mathrm{G}$, using a well-conditioned Beckman glass electrode

\footnotetext{
${ }^{2}$ No. 140 sieve of U. S. Standard Sieve Series.
} 
as a reference electrode. The voltage difference between the reference and experimental electrodes obtained in the buffer of $\mathrm{pH} 2$ was taken as the zero departure. This reference point, for some of the glasses, proved to be an unfortunate choice, as the readings were more unsteady in this buffer than at other acid $\mathrm{pH}$ values. ${ }^{3}$ The data for $\mathrm{pH}$ response $(\mathrm{mv}$ per $\mathrm{pH})$ were calculated from the voltage readings at $\mathrm{pH} 4.1$ and 8.2 .

The voltage data presented in this paper generally represent the best performance recorded for an electrode from a given glass. These optimum values were obtained for periods ranging from a few minutes

\footnotetext{
3 This unsteady "zero" voltage feature was undoubtedly associated with the chemical durability of the glass. Differences in appearance of the specimens and tarnishing of the surface upon exposure to the acid buffers were evident, although surface alteration could not be definitely demonstrated by the interferometer.
}

after the electrodes were prepared, for some glasses, to several days for others, depending on the life span of the electrodes as dictated by the chemical durability of the glasses.

The glasses investigated were from a series furnished by F. W. Glaze and J. M. Florence as a part of their general study of infrared transmittance of glasses $[25,26]$. The compositions of these glasses were computed from the batch and are identified throughout the text of this paper as weight percent in the ratio of $\mathrm{Na}_{2} \mathrm{O}: \mathrm{PbO}: \mathrm{SiO}_{2}$.

\section{Results and Discussion}

Typical data for hygroscopicity, chemical durability, voltage departure, and $\mathrm{pH}$ response for the $\mathrm{Na}_{2} \mathrm{O}-\mathrm{PbO}-\mathrm{SiO}_{2}$ glasses are listed in table 1.

TABLE 1. Hygroscopicity (water sorbed), $\mathrm{pH}$ response and chemical durability of some $\mathrm{Na}_{2} \mathrm{O}-\mathrm{PbO}-\mathrm{SiO}_{2}$ glasses

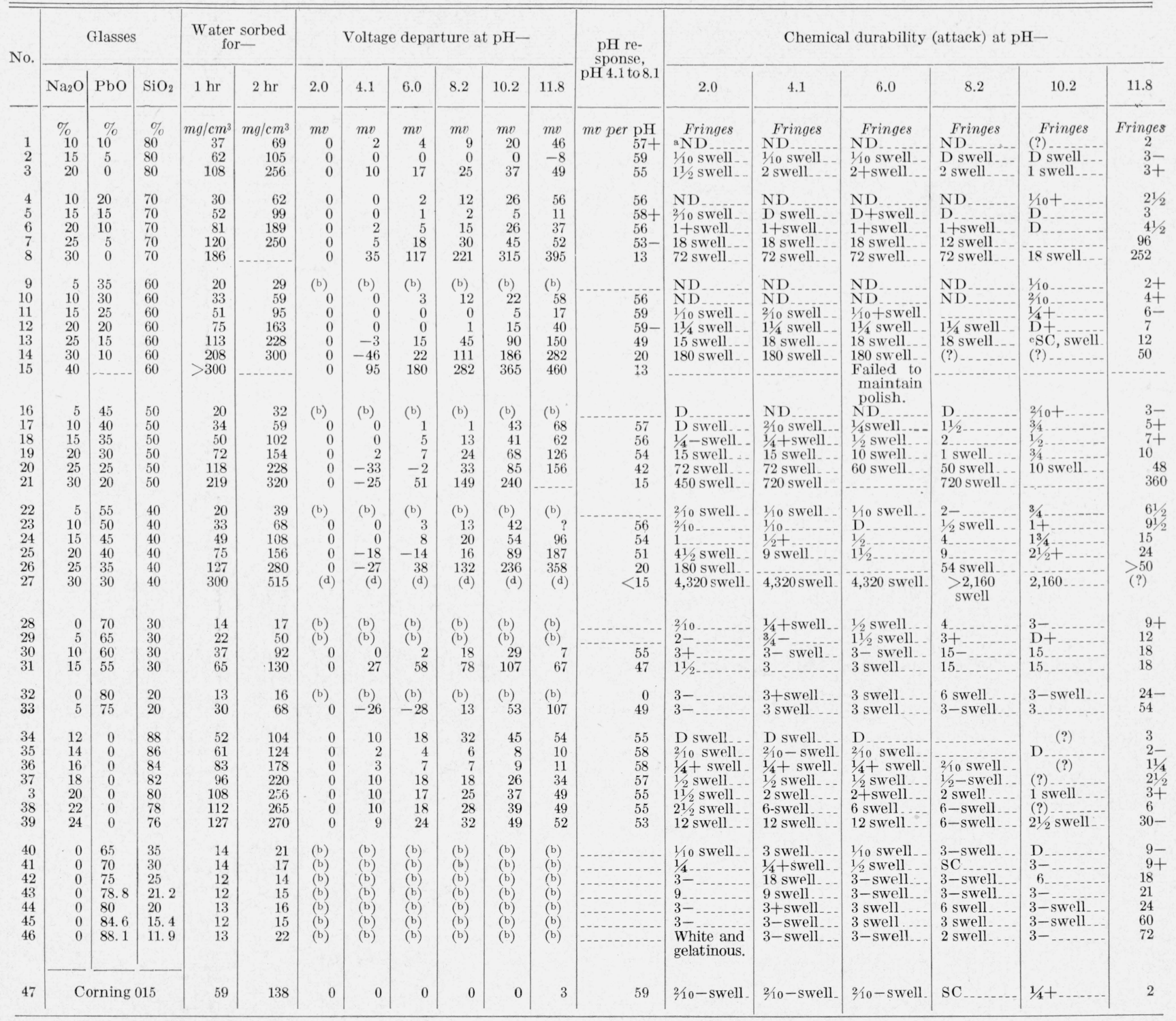




\section{Hygroscopicity and $\mathrm{pH}$ Response}

Figure 1 illustrates the results obtained upon plotting the $\mathrm{pH}$ response of these glasses against the hygroscopicity. As was the case for the $\mathrm{Na}_{2} \mathrm{O}$ $\mathrm{CaO}-\mathrm{SiO}_{2}$ series [13], these glasses also fall into distinct family groups of equal percentage of $\mathrm{SiO}_{2}$. The curves for each family in which sufficient members could be prepared without devitrification passed through a region of optimum performance. Electrodes from the glasses of very low hygroscopicity gave little or no $\mathrm{pH}$ response, while those of intermediate hygroscopicity more nearly approached the theoretical. All glasses to the right of the optimum showed a falling off in $\mathrm{pH}$ function, which was accompanied by a progressive decrease in chemical durability (table 1, figs. 2 to 15, incl.) with increasing hygroscopicity. Thus, the suggestion that a low $\mathrm{pH}$ response might be used as an indicator of serviceability of optical glasses [27] must be accepted with reservations, because only the glasses of low $\mathrm{pH}$ response and low hygroscopicity possess any degree of acceptable serviceability, whereas those of low $\mathrm{pH}$ response and high hygroscopicity are accompanied by poor chemical durability and poor serviceability.

\section{Chemical Durability and Voltage Departure}

A visual comparison of the chemical durability and voltage departure characteristics of those family groups of glasses having like $\mathrm{SiO}_{2}$ content shown in figure 1 can be obtained from inspection of figures 2 to 8 in which the above properties have been plotted over an extended $\mathrm{pH}$ range. In some cases the correlation of voltage departure with the chemical durability may be confusing or even appear contradictory, but if one keeps in mind that low hygroscopicity as well as poor chemical durability contributes to voltage departures from the theoretical, order is established from the apparent chaos. For example, in the family for 80 percent of $\mathrm{SiO}_{2}$ (fig. 2 ) the member 15:5:80 ${ }^{4}$ more nearly approaches the hygroscopicity and chemical durability characteristics of Corning $015[6,29]$ than any of the others, and at the same time its voltage characteristics are the best of the 80 percent $\mathrm{SiO}_{2}$ group. The large voltage departures for glass $20: 0: 80$ is due to the inferior durability compared to 015 , whereas the large departures for glass 10:10:80 results from its low hygroscopicity.

For the family of 70 percent of $\mathrm{SiO}_{2}$ (fig. 3 ), the glass 15:15:70 has the best voltage characteristics of the group. Its hygroscopicity and chemical durability characteristics also more nearly duplicate 015 than do any of the other members studied. Glass 10:20:70 has much lower hydroscopicity than 015, while the remaining members have poorer chemical durabilities over the entire $\mathrm{pH}$ range.

The same qualitative conditions prevail for the 60 percent $\mathrm{SiO}_{2}$ family (fig. 4), in which glass 15:25:60

\footnotetext{
${ }^{4} \mathrm{~A}$ glance at fig. 2 shows an apparent discrepancy between the voltage departure and the chemical durability value at $\mathrm{pH} 11.8$ for glasses 15:5:80 and 015 However, there is no reason to suppose that the increment of voltage departure per unit of attack for the soda-lead-silica glasses would be the same as for that of the soda-lime-silica system.
}

has the least votage departure and at the same time, its hygroscopicity and chemical durability characteristics more nearly approach 015 than do any of the other members of this group. The members with low hygroscopicity have voltage departures in accord with their respective water-sorbing capacities. The other members having poorer chemical durabilities than 015 have voltage departures that are qualitatively in the same order as their durabilities.

None of the glasses from the 50 percent $\mathrm{SiO}_{2}$ (fig. 5) family gave satisfactory voltages, but their relative order of performance can be readily ascertained by a glance at their hydroscopicity and chemical durability characteristics. Some of the chemical durability curves for this family group exhibited an abnormal attack at $\mathrm{pH} 8$ with some improvement at $\mathrm{pH} 10$, followed in turn by vigorous attack at $\mathrm{pH}$ 11.8. The same feature is exhibited to a more exaggerated degree for the 40 percent $\mathrm{SiO}_{2}$ series (fig. 6). For the 30 percent $\mathrm{SiO}_{2}$ group, the same durability characteristics persist, al though in a somewhat confused fashion (fig. 7) This particular type of chemical durability curve has been previously reported for some optical glasses [28].

Several of the electrodes whose voltage departure curves are shown in figures $4,5,6$, and 8 exhibited large negative departures in the acid range [11].

The emf behavior of the glasses for the families 40 percent, 30 percent, and 20 percent of $\mathrm{SiO}_{2}$ is in no case in accord with the straight-line relation of the Nernst equation. The glasses of very low hygroscopicity 5:55:40, 0:70:30, 5:65:30, and 0:80:20 failed to develop any definite $\mathrm{pH}$ response. The remaining glasses gave erratic electrode performance to accompany their erratic chemical durability curves. The dashed lines for the voltage departure for glasses such as 5:55:40 and 30:30:40 in figure 6 and for other glasses in figures $4,5,7$, and 8 are included merely to emphasize that glasses having very low hygroscopicity and those at the other extreme having such high hygroscopicity values and poor chemical durability as to behave as punctured electrodes, approach the theoretical limiting voltage for an electrode possessing no hydrogen electrode function [14].

Such glasses as 5:65:30 and 5:75:20 (table 1, and figs. 7 and 8) serve well to illustrate that low hygroscopicity is not an indicator of good chemical durability. These glasses of low hygroscopicity and poor chemical durability maintain clear surfaces in air, but tarnish rapidly in the buffer solutions.

None of the glasses containing only lead oxide and silica had sufficient hygroscopicity to produce electrodes showing any $\mathrm{pH}$ function (table 1 ).

The behavior of a limited number of glasses with 0 percent of lead oxide is included in table 1 for comparison. However, as but two of these (20:0:80 and 30:0:70) fit into the family groups, a discussion of these glasses will be postponed to a later publication on the $\mathrm{Na}_{2} \mathrm{O}-\mathrm{K}_{2} \mathrm{O}-\mathrm{SiO}_{2}$ system. It is of interest to note that the $\mathrm{pH}$ response of electrodes prepared from glass 12:0:88 was less than that expected from the hygroscopicity and chemical durability values. This is not surprising, as difficulty was encountered 
in melting the batch, and the tubes obtained consisted of stringy, partially crystallized glass [29].

\section{Effect of Composition on Hygroscopicity, Chemical Durability, and $\mathrm{pH}$ Response}

To further emphasize the orderly interrelation between the hygroscopicity, chemical durability, and voltage performance of the $\mathrm{Na}_{2} \mathrm{O}-\mathrm{PbO}-\mathrm{SiO}_{2}$ glasses, these properties were plotted against the $\mathrm{PbO}$ content for each family in figures 9 to 15 . From the hygroscopicity curves, it is evident that all glasses having low water "sorption" properties fail to develop the full theoretical $\mathrm{pH}$ response.

The chemical durability curves presented are for the extremes of $\mathrm{pH}$ studied, namely $\mathrm{pH} 2$ and 11.8 . These curves illustrate the marked difference in chemical durability behavior for glasses in acid and basic solutions, with swelling predominating in the acid pH range and solution occurring at high alkalinity. The divergence of these curves serves to emphasize the compositions at which marked durability differences appear. Further, a glance at the $\mathrm{pH}$ response curves reveals that the hydrogen electrode function of the glasses starts declining at the same compositions at which the chemical durabilities show a marked change.

The question always arises, do the chemical or physical properties of a series of glasses reflect any of the critical compositions of the phase-equilibrium diagram? In figures 9 to 14, dashed lines are drawn near the compositions at which a change of primary phase occurs [30]. In figure 10 a sharp change in the chemical durability of the series appears between the successive glass members, one of which falls in the composition range where $\mathrm{Na}_{2} \mathrm{O} .2 \mathrm{SiO}_{2}$ is the primary phase, and the other in which $\mathrm{SiO}_{2}$ becomes the primary phase. A similar correspondence appears for the $\mathrm{pH}$ response-composition curve in figure 10. The same features seem to be indicated in figures 11 and 12 . The $\mathrm{pH}$ response of the electrode prepared from the glass of 20 percent of $\mathrm{PbO}$ in figure 11 appears to be "too good" for convincing agreement. A comparison of the durability data for this glass with other glasses of table 1 implies that a lower $\mathrm{pH}$ response from this glass might well be expected. The cross sections of the phase-equilibrium diagram for the data presented in figures 13 and 14 are complicated and the experimental data inadequate for specific conclusions, yet the over-all picture is one of correspondence to the major composition changes. Figure 15 indicates that the region of high percentages of $\mathrm{PbO}$ is not a good one to explore for glasses having satisfactory $\mathrm{pH}$ response characteristics.

An over-all picture of the hygroscopicity versus composition for the $\mathrm{Na}_{2} \mathrm{O}-\mathrm{PbO}-\mathrm{SiO}_{2}$ glasses is presented in the ternary diagram, figure 16 . The compositions of equal hygroscopicity (isosorbs) were obtained by interpolation of the observed data. The glass compositions that gave electrodes that developed $\mathrm{pH}$ functions as high as $56 \mathrm{mv} / \mathrm{pH}$ between $\mathrm{pH} 4$ and 8 are included in the shaded area, while those glasses that produced electrodes developing the full $59 \mathrm{mv} / \mathrm{pH}$ are connected by a heavy dashed line. The glasses of higher $\mathrm{Na}_{2} \mathrm{O}$ content and higher hygroscopicity gave electrodes that fell appreciably below the theoretical voltage and were also short-lived. It appears that the $\mathrm{Na}_{2} \mathrm{O}-\mathrm{PbO}$ $\mathrm{SiO}_{2}$ glasses fall into the same three groups that were characteristic of the $\mathrm{Na}_{2} \mathrm{O} \cdot \mathrm{CaO} \cdot \mathrm{SiO}_{2}$ series [13]: A, glasses that are too "dry" for successful electrodes; $\mathrm{B}$, glasses that produce successful electrodes; and C, glasses having poor chemical durability, which are too "wet". Actually, the area B is also very much reduced because of poor durability of its members.

\section{Conclusions}

The $\mathrm{Na}_{2} \mathrm{O}-\mathrm{PbO}-\mathrm{SiO}_{2}$ series of glasses appear to follow the generalizations for the hydrogen electrode behavior of glasses as outlined in the introduction of this report. All the members having very low hygroscopicity gave electrodes that failed to develop the theoretical voltage predictable from the Nernst equation at room temperatures. Likewise, the electrodes from glasses of very poor chemical durability failed to develop the full theoretical voltage. Although it is improbable that the best possible of the $\mathrm{Na}_{2} \mathrm{O}-\mathrm{PbO}-\mathrm{SiO}_{2}$ glasses for $\mathrm{pH}$ measurement were included in this series, it is obvious that those members that most nearly approached the hydgroscopicity and chemical durability characteristics of Corning 015 most nearly approached the ideal hydrogen electrode performance at $25^{\circ} \mathrm{C}$. Poor chemical durability in the alkaline range, even for the best glasses produced, is one of the major factors limiting their usefulness.

Most of the durability measurements reported are qualitative. They are of interest in demonstrating the initial alteration of glass surfaces during attack by aqueous solutions, especially for the acid buffers in which many of the glasses exhibited a rapid rate of swelling. The pH-response and chemical-durability curves appear to reflect some of the critical compositions of the phase equilibrium diagram for the $\mathrm{Na}_{2} \mathrm{O}-\mathrm{PbO}-\mathrm{SiO}_{2}$ system.

\section{References}

[1] M. Cremer, On the causes of the electromotive properties of tissue and a discussion of polyphase electric cells, Z. Biol. 47, 562 (1906)

[2] F. Haber and Z. Klemensiewicz, On electrical interfacial potentials, Z. physik. Chem. 6\%, 385 (1909).

[3] G. Borelius, Interfacial potentials of solutions in contact with insulators, Ann. physik. [4] 45, 929 (1914).

[4] H. Freundlick and Rona, The relation between electrokinetic potential pressure and the electric force at phase interfaces, Sitz. preuss. Akad. Wiss. 20, 397 (1920).

[5] W. S. Hughes, The potential difference between glass and electrolytes in contact with glass, J. Am. Chem. Soc. 44, 2860 (1922).

[6] M. Dole, Glass electrode (John Wiley \& Sons, Inc., New York N. Y., 1941).

[7] D. A. MacInnes and M. Dole, The behavior of glass electrodes of different compositions, J. Am. Chem. Soc. 52, 29 (1930). 
[8] George A. Perlev, Glasses for measurement of $\mathrm{pH}$, Anal. Chem. 21, 394 (1949); U. S. Patent 2,444,845 (1948).

[9] B. Lengyel and E. Blum, The behavior of the glass electrode in connection with its chemical composition, Trans. Faraday Soc. 30, 461 (1934).

[10] W. E. L. Brown, The measurement of hydrogen-ion concentration with glass electrodes, J. Sci. Instr. 2, 12 (1924).

[11] D. A. MacInnes and D. Belcher, Further studies of the glass electrode, J. Am. Chem. Soc. 53, 3315 (1931).

[12] Donald Hubbard, Hygroscopicity of optical glasses as an indicator of serviceability, J. Research NBS $\mathbf{3 6}$, 365 (1946) RP1706.

[13] Donald Hubbard, Given W. Cleek, and Gerald F. Rynders, Electrode Function ( $\mathrm{pH}$ response), hygroscopicity, and chemical durability of $\mathrm{Na}_{2} \mathrm{O}-\mathrm{CaO}-\mathrm{SiO}_{2}$ glasses, J. Research NBS 45, 247 (1950) RP2076.

[14] Gerald F. Rynders, Oscar H. Grauer and Donald Hubbard, Electrode Function ( $\mathrm{pH}$ response) of soda-silica glasses, J. Research NBS 41, 273 (1948) RP1923.

[15] Donald Hubbard, Edgar H. Hamilton and A. N. Finn, Effect of the solubility of glass on the behavior of the glass electrode, J. Research NBS 22, 339 (1939) RP1187.

[16] G. Buchbock, A property of the glass electrode, Z. physik. Chem. 156A 232 (1931).

[17] Donald Hubbard and Gerald F. Rynders, Voltage anomalies of the glass electrode and the chemical durability of the glass, J. Research NBS 39, 561 (1947) RP1848.

[18] James W. McBain, The mechanism of the adsorption ("sorption") of hydrogen on carbon, Phil. Mag. 18, 916 (1909); Z. physik, chem. 68, 471 (1909).

[19] Relative durability of optical glass, NBS Technical News Bulletin No. 221, 88 (1935).
[20] E. Berger, Grundsatzliches uber die chemische angreifbarkeit von glasen I, Glastech. Ber. 14, 351 (1936).

[21] Donald Hubbard and Gerald F. Rynders, Effect of annealing and other heat treatments on the $\mathrm{pH}$ response of the glass electrode, J. Research NBS $\mathbf{4 0}$, 105 (1948) RP1859.

[22] Donald Hubbard and Gerald F. Rynders, Thickness of inhibiting films on glass electrode surfaces, J. Research NBS 41, 163 (1948) RP1915.

[23] H. T. S. Britton, Hydrogen ions, i, 3d ed., 88C, p. 313 (D. Van Nostrand Co., Inc., New York, N. Y., 1943).

[24] M. R. Thompson, A metal-connected glass electrode, BS J. Research 9, 833 (1932) RP 511.

[25] Jack M. Florence, Francis W. Glaze, Clarence H. Hahner, and Ralph Stair, Transmittance of near infra red energy by binary glasses, J. Research NBS 41, 623 (1948) RP1945.

[26] J. M. Florence, C. C. Allshouse, F. W. Glaze, C. H. Hahner. The absorptance of near-infrared energy by certain glasses, J. Research NBS 45, 121 (1950) RP2118.

[27] Donald Hubbard, Hygroscopicity and electrode function ( $\mathrm{pH}$ response) of glasses as a measure of serviceability, J. Research NBS 36, 511 (1946) RP1719.

[28] Donald Hubbard and Edgar H. Hamilton, Studies of the chemical durability of glass by an interferometer method, J. Research NBS $\mathbf{2 7}, 143$ (1941) RP1409.

[29] W. S Hughes, On Haber's glass cell, J. Chem. Soc. 491 (1928).

[30] K. A. Krakou, E. J. Mukhin, and M. S. Heinrich, Equilibrium diagram of the ternary system $\mathrm{Na}_{2} \mathrm{SiO}_{3}-$ $\mathrm{PbSiO}_{3}-\mathrm{SiO}_{2}$, Compt. rend. acad. sci. URSS 14, 281 (1937).

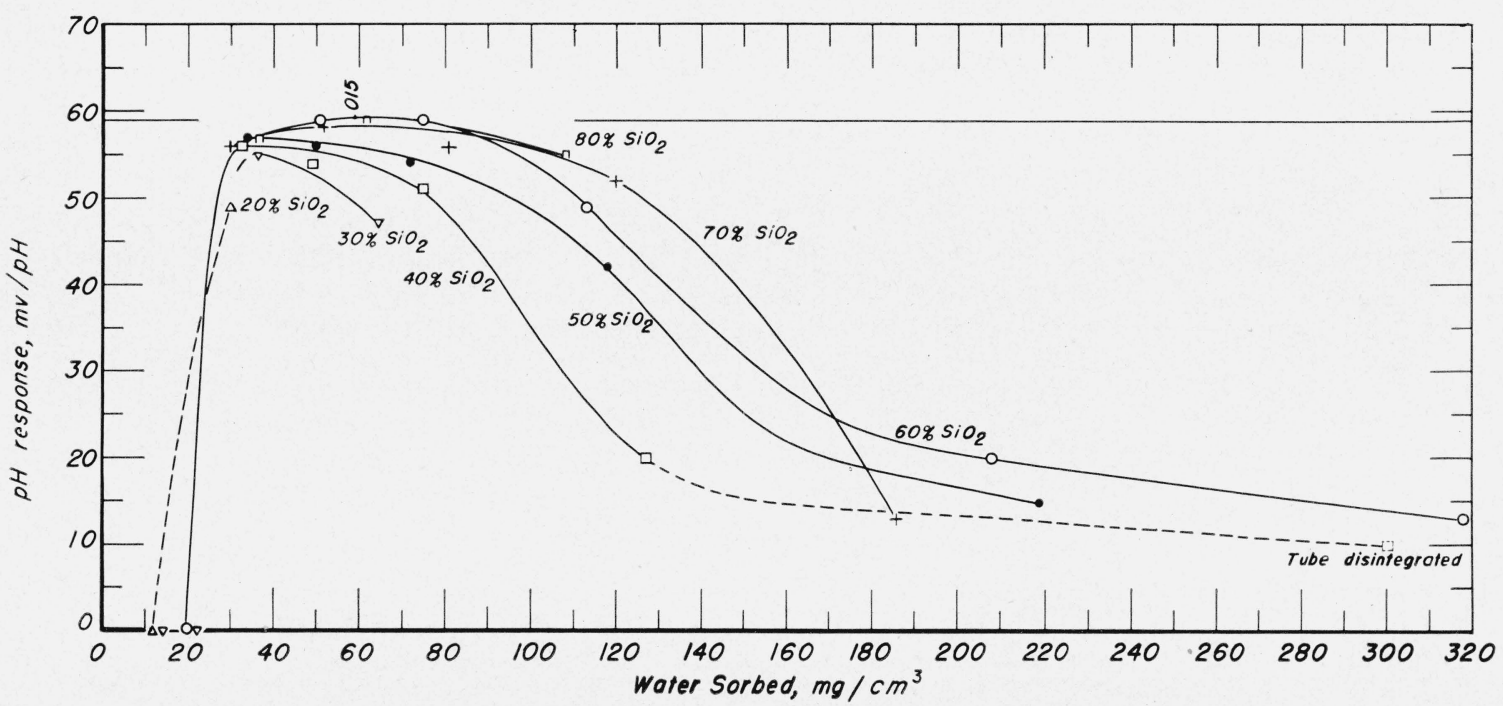

Figure 1. Comparison of the hygroscopicity (water sorbed, 1 hr) and $\mathrm{pH}$ response of a series of $\mathrm{Na}_{2} \mathrm{O}-\mathrm{PbO}_{-} \mathrm{SiO}_{2}$ glasses . 

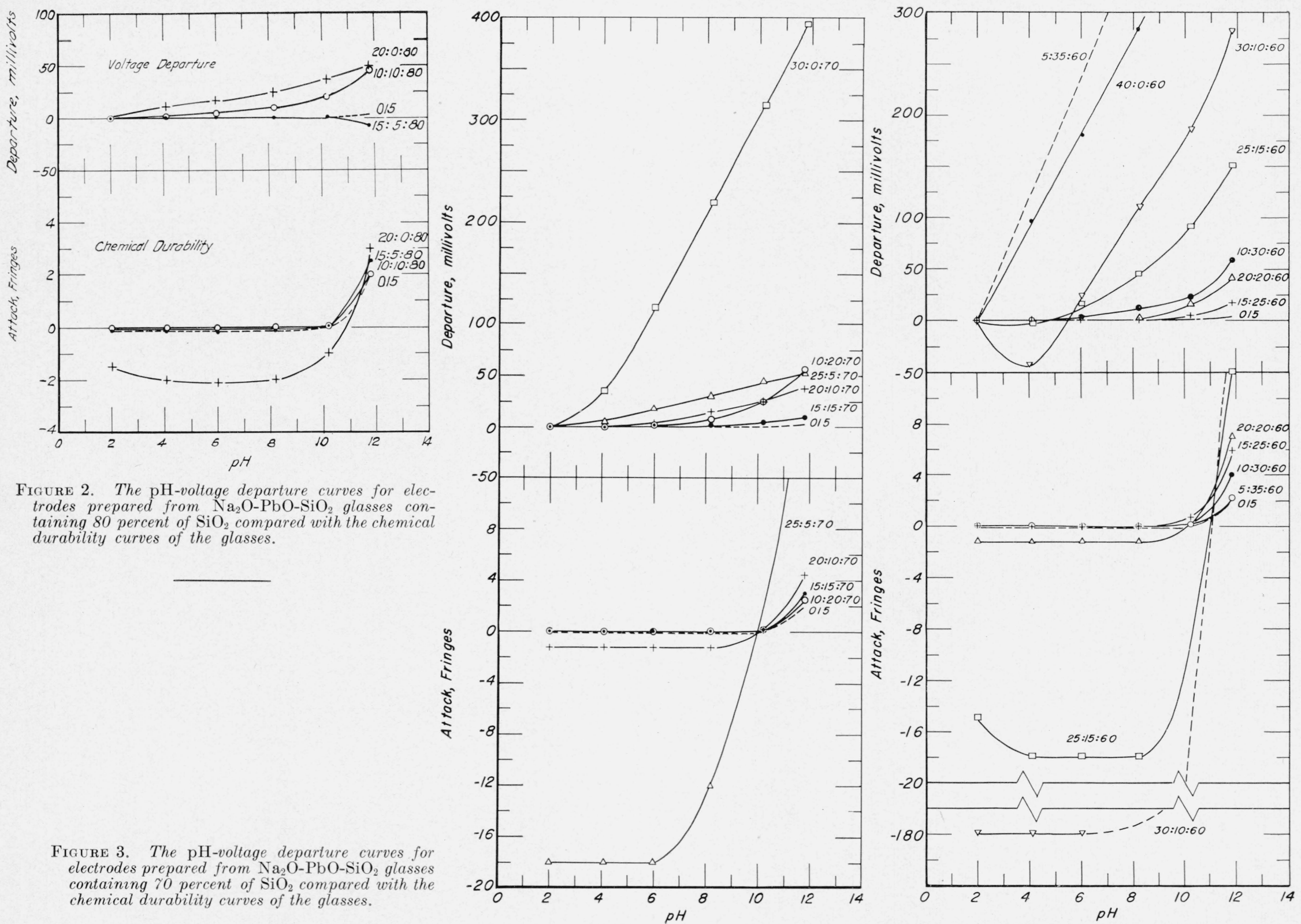

IGURE 3. The pH-voltage departure curves for electrodes prepared from $\mathrm{Na}_{2} \mathrm{O}-\mathrm{PbO}-\mathrm{SiO}_{2}$ glasses chemical durability curves of the glasses.

trodes prepared from taining 80 percent of $\mathrm{SiO}_{2}$ compared with the chemical durability curves of the glasses. 


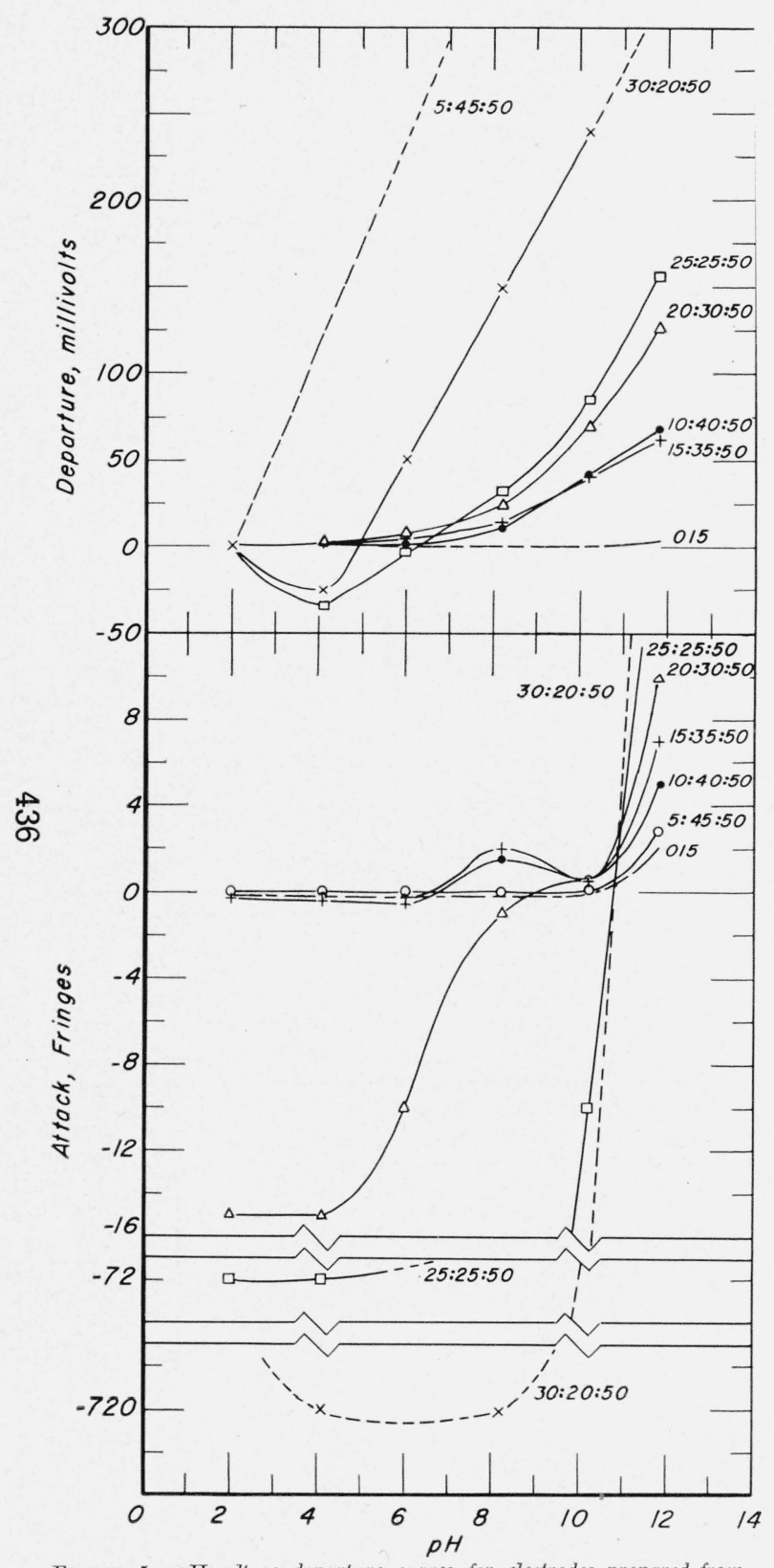
FIGURE 5. $\mathrm{pH}$-voltage departure curves for electrodes prepared from
$\mathrm{Na}_{2} \mathrm{O}-\mathrm{PbO}-\mathrm{SiO}_{2}$ glasses containing $50 \%$ of $\mathrm{SiO}_{2}$ compared with chemical durability curves of the glasses.
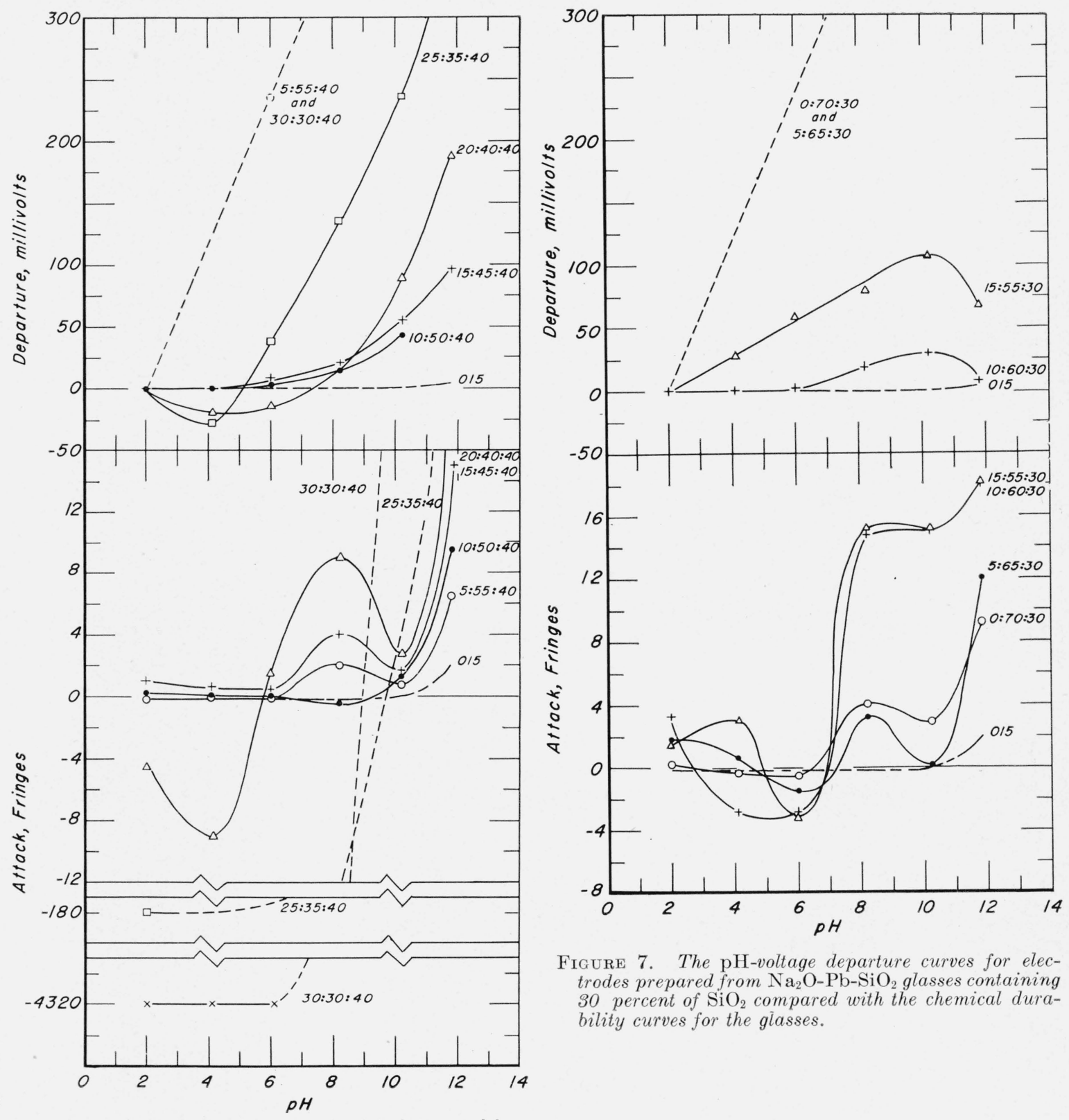

FiguRE 7. The $\mathrm{pH}$-voltage departure curves for electrodes prepared from $\mathrm{Na}_{2} \mathrm{O}-\mathrm{Pb}-\mathrm{SiO}_{2}$ glasses containing 30 percent of $\mathrm{SiO}_{2}$ compared with the chemical durability curves for the glasses.
FIGURE 6. $\mathrm{pH}$ voltage departure curves for electrodes prepared from durability curves of the glasse. 


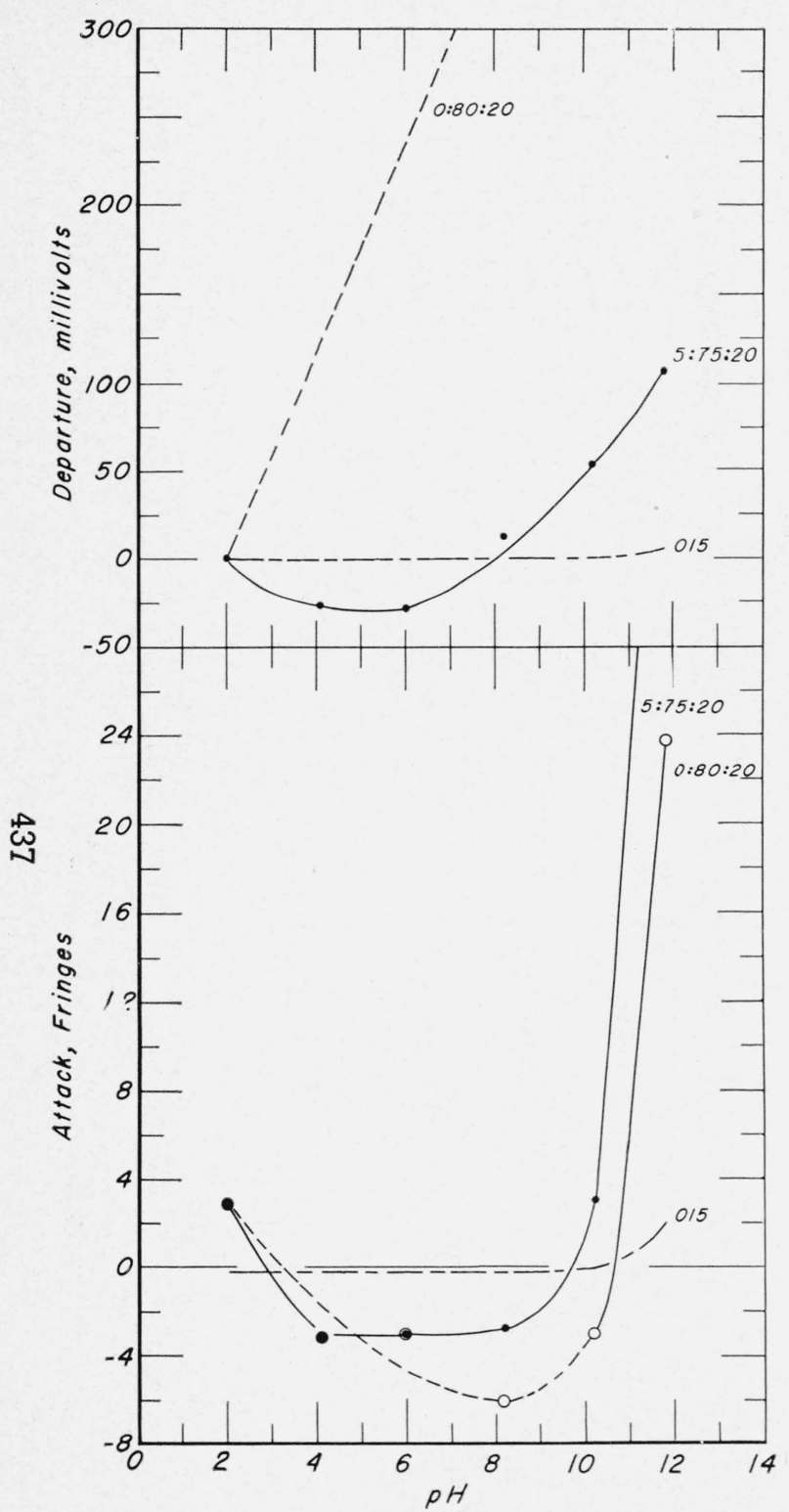

Figure 8. The pH-voltage departure curves for electrodes prepared from $\mathrm{Na}_{2} \mathrm{O}-\mathrm{PbO}-\mathrm{SiO}_{2}$ glasses containing 20 percent of $\mathrm{SiO}_{2}$ compared with the chemical durability curves of the glasses.

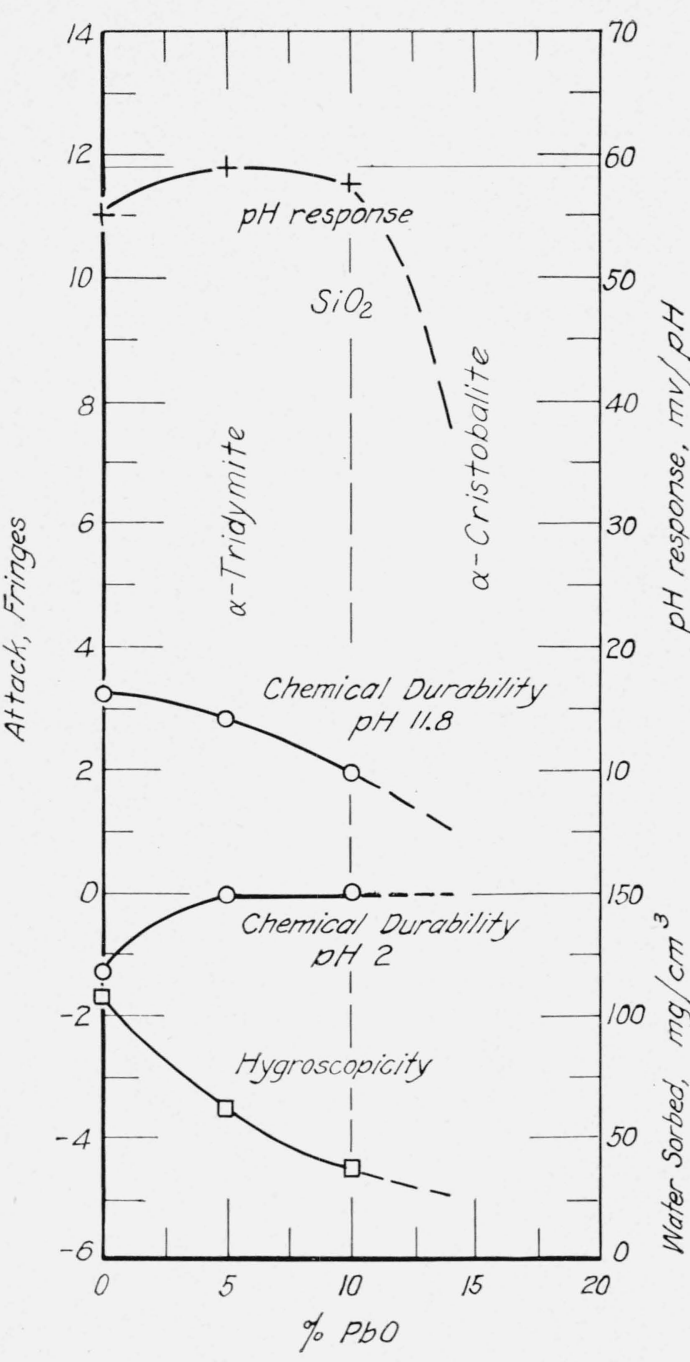

Figure 9. Values for pH-response, hygroscopicity, and chemical durability at $\mathrm{pH} 2$ and 11.8 plotted against the percentage of $\mathrm{PbO}$ for $\mathrm{Na}_{2} \mathrm{O}-\mathrm{PbO}-\mathrm{SiO}_{2}$ glasses containing 80 percent of $\mathrm{SiO}_{2}$

Figure 10. Values for $\mathrm{pH}$-response, hygroscopicity, and chemical durability at $\mathrm{pH} 2$ and 11.8 plotted aaainst the percentage of $\mathrm{PbO}$ for $\mathrm{Na}_{2} \mathrm{O}-\mathrm{PbO}-\mathrm{SiO}_{2}$ glasses containing 70 percent of $\mathrm{SiO}_{2}$.

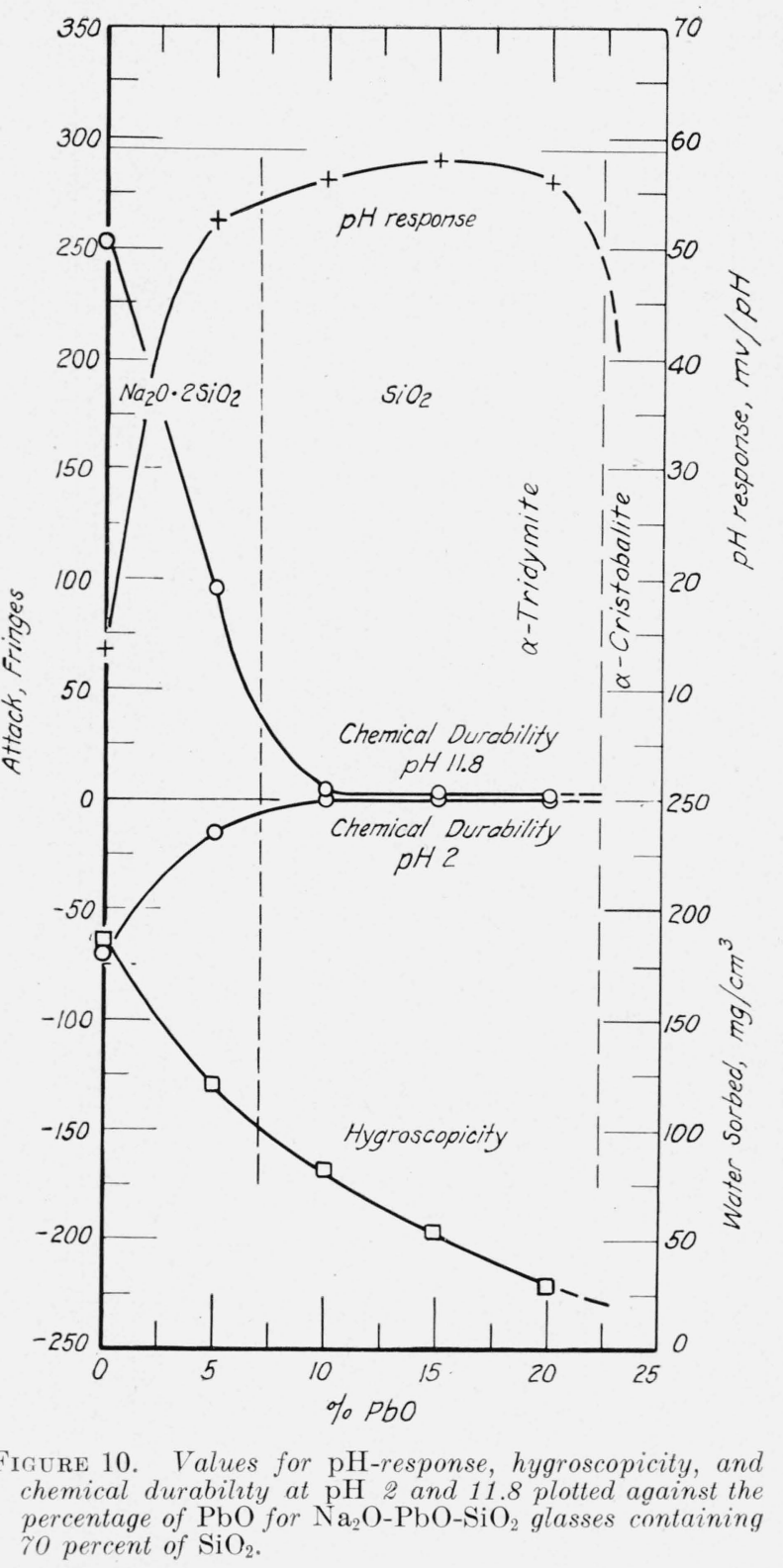



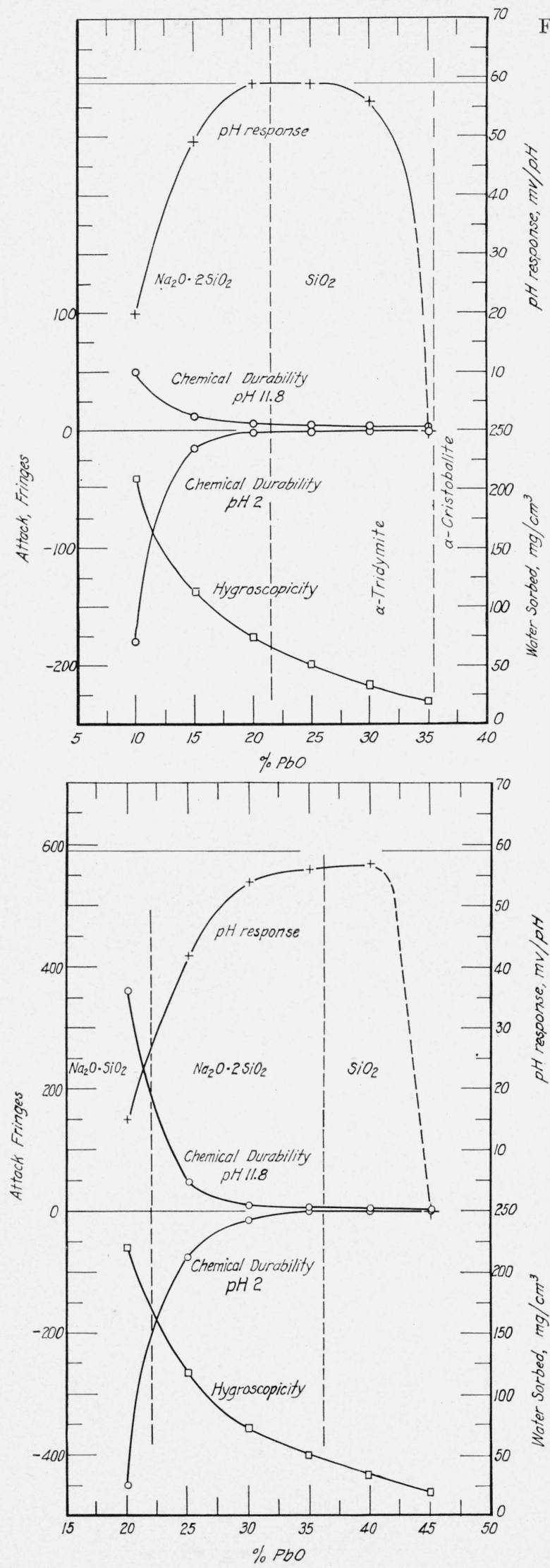

Figure 11. Values for pH-response, hygroscopicity, and chemical durability at $\mathrm{pH} 2$ and 11.8 plotted against the percentage of $\mathrm{PbO}$ for $\mathrm{Na}_{2} \mathrm{O}-\mathrm{PbO}-\mathrm{SiO}_{2}$ glasses containing 60 percent of $\mathrm{SiO}_{2}$.

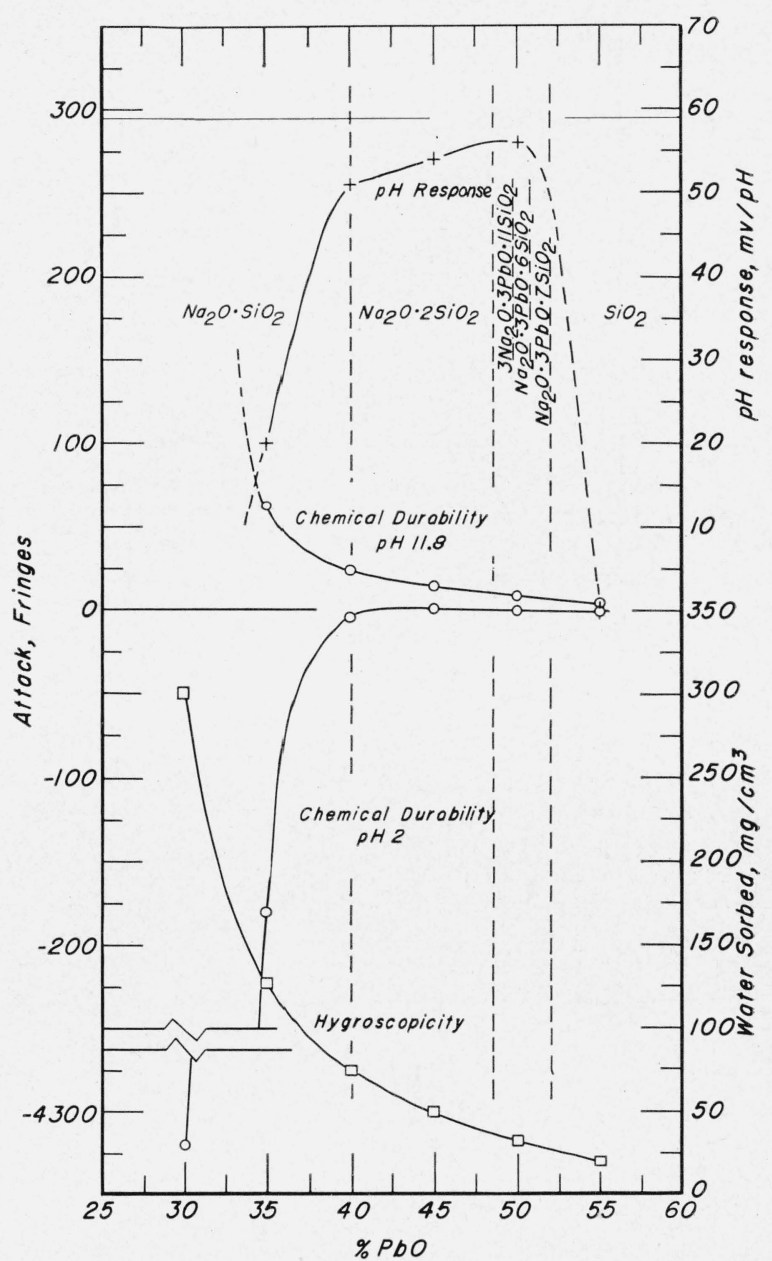

Figure 13. Values for pH-response, hygroscopicity, and chemical durability at $\mathrm{pH} 2$ and 11.8 plotted against the percentage of $\mathrm{PbO}$ for $\mathrm{Na}_{2} \mathrm{O}-\mathrm{PbO}-\mathrm{SiO}_{2}$ glasses containing 40 percent of $\mathrm{SiO}_{2}$.

Figure 12. Values for pH-response, hygroscopicity, and chemical durability at $\mathrm{pH} 2$ and 11.8 plotted against the percentage of $\mathrm{PbO}$ for $\mathrm{Na}_{2} \mathrm{O}-\mathrm{PbO}-\mathrm{SiO}_{2}$ glasses containing 50 percent of $\mathrm{SiO}_{2}$. 


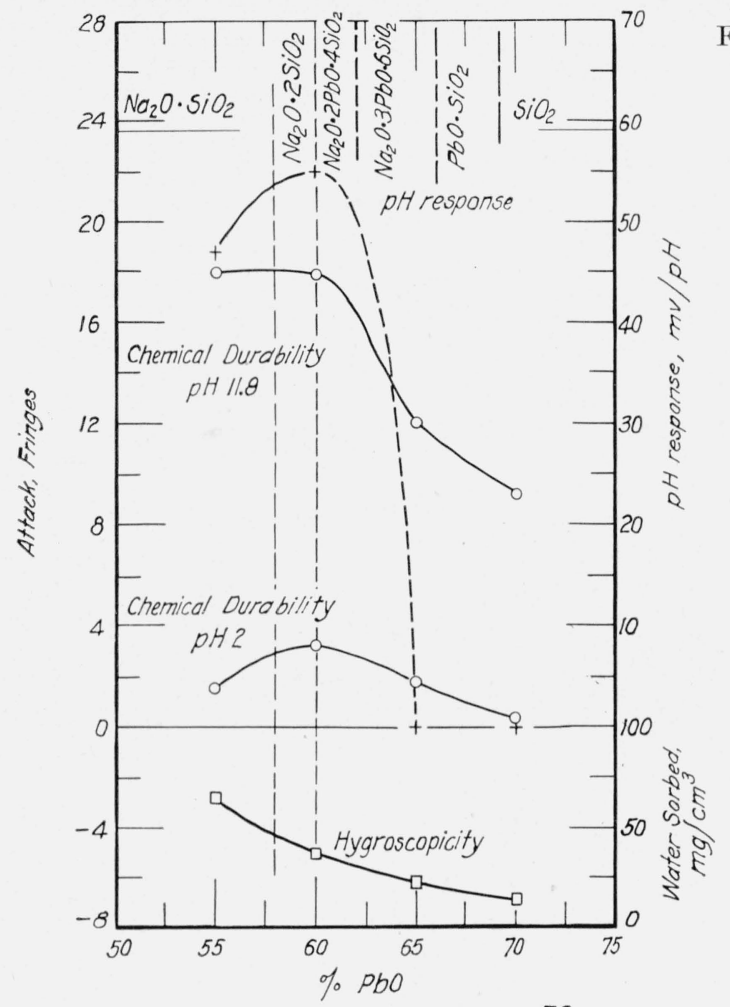

Figure 14. Values for pH-response, hygroscoprcity, and chemical durability at $\mathrm{pH} 2$ and 11.8 plotted against the percentage of $\mathrm{PbO}$ for $\mathrm{Na}_{2} \mathrm{O}-\mathrm{PbO}-\mathrm{SiO}_{2}$ glasses containing 30 percent of $\mathrm{SiO}_{2}$.

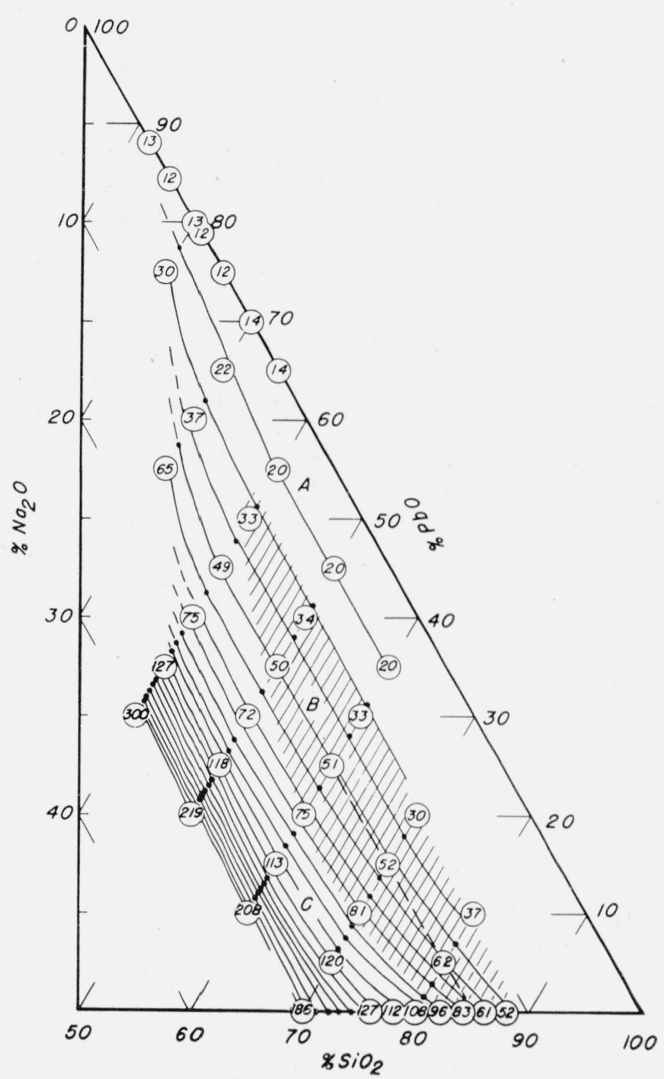

Figure 16. Hygroscopicity of $\mathrm{Na}_{2} \mathrm{O}-\mathrm{PbO}-\mathrm{SiO}_{2}$ glasses for 1-hr exposure showng lines of equal hygroscopicity (iso-sorbs for intervals of $10 \mathrm{mg} / \mathrm{cm}^{3}$ ) and the shaded area over which electrodes prepared from these glasses developed as high as $56 \mathrm{mv} / \mathrm{pH}$.

The heavy dashed line links the only three glasses of the series that developed the theoretical $59 \mathrm{mv} / \mathrm{pH}$ at $25^{\circ} \mathrm{C}$.

Figure 15. Values for pH-response, hygroscopicaty, and chemical durability at $\mathrm{pH} 2$ and 11.8 plotted against the percentage of $\mathrm{PbO}$ for $\mathrm{Na}_{2} \mathrm{O}-\mathrm{PbO}-\mathrm{SiO}_{2}$ glasses containing \& 20 percent of $\mathrm{SiO}_{2}$.

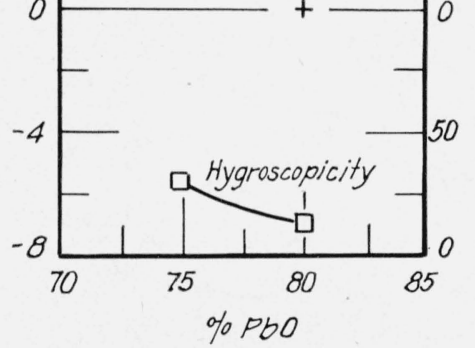

की है है हो

Washington, May 24, 1950. 